\title{
Gambaran Pelaksanaan sistem komunikasi RS-Puskesmas-Keluarga pada Bayi Resiko Tinggi
}

\section{Yeni Rustina \\ Wiwin Wiarsih \\ Elfi Syahreni}

Tim Dosen Keperawatan maternitas dan Komunitas FIK UI

Sistem komunikasi merupakn suatu sistem sarana yang menunjang kesinambungan asuhan keperawatan bayi risiko tinggi di komunitas setelah bayi pulang dari rumah sakit. Perawatan di rumah merupakan tanggung jawa keluarga dan dipantau oleh perawat puskesmas melalui kunjungan rumah. Perawatan lanjutan dapat dilaksanakan secara optimal apabila terjalin komunikasi yang baik antara RS-Puskesmas-Keluarga. Penelitian ini merupakan penelitian deskriptif yang bermaksud untuk mengevaluasi sistem komunikasi RS-Puskesmas-Keluarga dan keluarga yang ada saat ini dan faktor-faktor yang mempengaruhinya. Sampel terdiri dari 3 kelompok yaitu ibu-ibu dengan bayi risiko tinggi berjumlah 61 orang, perawat RS dan perawat Puskesmas yang merawat bayi risiko tinggi masing-masing berjumlah 66 orang dan 15 orang. Lokasi penelitian dilakukan di RSUPN Ciptomangunkusumo, RS Persahabatan, dan 6 puskesmas kecamatan di wilayah Jakarta Timur (Duren Sawit, Kramat Jati, makasar, Pasar Rebo, Cipayung, Cakung).

Hasil yang diperoleh menunjukkan bahwa sistem komunikasi RS-Puskesmas-Keluarga yang ada saat ini kurang begitu baik. Hal ini digambarkan oleh rendahnya kunjungan rumah perawat Puskesmas (6,56\%), sementara itu ibu-ibu bayi risiko tinggi (83,61\%) menyatakan perlunya kunjungan rumah perawat Puskesmas. Kurangnya kesadaran ibu-ibu bayi risiko tinggi akan pentingnya surat rujukan terlihat melalui survey ini, karena hanya 26,67\% perawat Puskesmas yang menerima surat rujukan. Materi penyuluhan yang didapat ibu-ibu bayi risiko tinggi dari perawat (RS dan Puskesmas) kurang memenuhi kebutuhan karena hanya mencakup perawatan umumdan pencegahan penyakit, serta sistem rujukan, tidak mencakup pertumbuhan dan perkembangan anak.

Kata kunci: rujukan, premature, perawatan lanjutan

One of the important facilities in the community health care services for the high risk babies is improvement of the communication system. Home visit and care have to be done and it's the responsibility of the Community Health Nurses and families. Home care It can be effective if there is a good communication system between Hospital, Community Health Centre and the families. This study is a descriptive research design which has a purpose to evaluate the communication system in Indonesian's Health care institution and the families.

The sample consist of three group, namely mothers with high risk babies, nurses in the hospital and community health service in East Jakarta.

The result shown in this study is that most of the mother's of high risk perceived that there is lack home careservice and they received lack of information (health education materials).

Key word: referral system, premature, advanced nursingcare 